\title{
Current Reflections Regarding Women's Participation in Mexico-United States Migration: Moving Towards a Quantitative Feminization of Migration?
}

\author{
Julio Santiago Hernández \\ University of Guadalajara \\ University Center of Tonalá
}

The purpose of this paper is to offer a statistical approach to the debate on the feminization of the MexicoUnited States migration process. For this, the flows or the "stock" of the Mexican migration of the last decade from different statistical sources available both in Mexico and in the United States are presented. The review suggests that women have historically been part of male migration, but unfortunately they have been poorly attended by scholars and when they did they were considered only as companions, relegating them to a secondary role in the migration process. However, as of the 1980s, the migration of women becomes an undeniable fact. Since then, more and more work began to be carried out from various disciplinary and theoretical perspectives that claimed the participation of Mexican women in international migration processes. This is evidenced by the analysis of the results of the recent decade, now more and more women are migrating autonomously in search of better employment opportunities and better living conditions for their families.

Keywords: women, international migration, work, feminization

\section{INTRODUCTION}

There has never been a greater movement of women than today in the history of mankind. Approximately 90 million women live outside their countries of origin, representing about half of the world's international migrants. However, women have long represented a significant percentage of migrants (ZLOTNIK, 2003). The difference at this time is not the migration scale or the inclusion of women in migration flows, which were previously mostly male, but the fact that an increasing number of women are migrating on their own decision (UN, 2006).

Indeed, on a global scale, women have played a significant role in international migration, which has increased relatively steadily since 1960, even though they are not yet in the majority (MARTÍNEZ, 2003). Nowadays, they are in the main immigration regions -strictly speaking, since 1990-; in contrast with the less developed regions, which keep similar proportions to those they had in 1960 (ZLOTNIK, 2003).

Among the less developed regions, Latin America has the highest proportion of women among international migrants, in a percentage similar to that of the more developed regions as a whole. This quantitative feminization on the intra-regional scale is a typical feature of migration in recent decades (VILLA and MARTÍNEZ, 2002). 
In Mexico, it was hard to find a consensus regarding the quantitative participation of women in USAMexico migration. Until before the 1980s, the migration of Mexicans to the United States had been recognized as predominantly male, so that women's participation in the migration process was considered marginal; however, the articles regarding the feminization of migration, consulted throughout this study, alluded to the fact that women began to achieve numerical importance after the approval of the reforms to the Immigration Reform and Control Act (IRCA) in the United States in 1986 (WOO, 2007). It was argued that the increase in the number of women participating in the migration flow was one of the most important changes in the characteristics of the migrant population and migration patterns, alluding to the fact that these women not only migrated to join their families, but also to obtain employment (CORNELIUS, 1988; BUSTAMANTE, 1988).

However, the opinions are not conclusive regarding a quantitative feminization of the migration of Mexicans to the United States. In this paper we resume this debate by analyzing the flows or "stock" of Mexican migration based on the question: to what extent are we moving towards a quantitative feminization of Mexico-United States migration due to the changes in the gender distribution of migration flows? the feminization term can be misleading if it is understood only as the absolute increase in the percentage of migrant women, when the phenomenon is much more complex than that. In fact, it is not only the presence of a greater number of women, but also the autonomous nature of the migration act, given that it is an eminently labor-related migration. ${ }^{1}$

\section{General Discussion}

The Invisibility of Mexican Women in Migration Analysis

Originally, the international migration study, and specifically the study of migrant employment to the United States, focused on male participation. When female migration was studied, it was immediately related to male migration, under the argument that women migrated only as companions of their husbands, fathers or brothers, and not as a decision and self-realization. Thus, there was little recognition of women's independent activity in the migration process. The following paragraphs summarize the essence of this statement:

\footnotetext{
"...if women migrated they did so as part of the family unit or came from areas where male migration was strong and had become an established pattern over the years" (MINES and JANVRY, 1982; REICHERT and MASSEY, 1979, 1981), and when they worked they found employment with their husbands...so that if the issue of male migration is resolved, so is that of female migration" (KOSSOUDJI and RANNEY, 1984: 1120).
}

This clearly shows the lack of recognition regarding the independent activity of women in the migratory process, which, together with the difficulty in reaching a consensus on the size of the female flow at that time, ended up justifying the fact that, when explaining the participation of migrant workers, the migration of women in the process was also understood (WOO, 1995; KOSSOUDJI and RANNEY, 1984).

\section{The Presence of Mexican Women in the Migration Process}

Mexican migration to the United States continued to be considered predominantly male, at least until before the 1980s. ${ }^{2}$ From that point on, the presence of the female population began to capture the attention of specialists, although there was no consensus among specialists regarding the quantitative participation of women in Mexico-United States migration. However, it was recognized as one of the most important changes in the characteristics of the migrant population and migration patterns, that women began to achieve significant levels of numerical importance after the passage of the reforms to the U.S. Immigration Reform and Control Act (IRCA) in October $1986,{ }^{3}$ better known as Simpson-Rodino Act (CORNELIUS, 1988; BUSTAMANTE, 1988; GONZÁLEZ DE LA ROCHA and ESCOBAR, 1990, and ARROYO ET AL., 1991). ${ }^{4}$ Since then, the "presence" of women has been an undisputed fact.

Research has also suggested that another change in recent years has been the fact that more and more women have been moving away from the roles or patterns traditionally assumed as partners or dependents 
of husbands, fathers, children or siblings, and have been assuming a more visible role of their own: that of migrants on their own initiative and for work reasons (CORNELIUS, 1988; BUSTAMANTE, 1988). This phenomenon of greater visibility on the one hand and greater autonomy on the other has been called the "feminization" of migration and has been established as one of the characteristics of modern international migration (CASTLES and MILLER, 1998). ${ }^{5}$

The discussion is not complete, first because there is no consensus on the quantitative participation of women in Mexico-United States migration. Second, because the term "feminization of migration" can be misleading in that it suggests, on the one hand, an absolute increase in the percentage of migrant women. And on the other hand, a "qualitative" change in the composition of these flows, such as the sustained increase in the proportion of women who migrate independently in search of employment.

However, we do not rule out that in recent years in our country a net feminization of flows has been possible, nor that more and more women migrate independently in search of work, instead of doing so as "dependents". In addition, it is evident that academics and policy makers have started to pay more attention to female migration and the role of gender in migration processes. This is not minor, as it has allowed further reflection even on concepts or ideas such as "feminization", which was considered to have already been resolved.

\section{Mexican Women Migrating to the United States}

Volume (Stock) of Mexican Women Residing in the United States

As a consequence of the intense migratory dynamism of past decades, the number of Mexicans residing in the neighboring country of the North reached a significant volume at the beginning of the century (LEITE, ANGOA and RODRÍGUEZ, 2009). Information from U.S. censuses shows that in 1970 there were 760,000 Mexicans living in the United States; in 1980 the number rose to nearly 2.2 million (see Table 1). The Mexican population continued to grow and consolidate in the following decades, assisted by the processes of labor immigration and family reunification (formal and informal). In 1990, the number of Mexicans in the United States increased to 4.3 million and in 2000 it reached 9.2 million, of which $45 \%$ were women. For 2010, the figure amounted to around 11.7 million people, where almost $46 \%$ were women.

In 2016 according to Migration Policy Institute (MPI) estimates based on the American Community Survey (ACS). It registered a total of around 11.6 million people, of which almost $48 \%$ were women, representing a small decrease in the participation of men and, consequently, an absolute increase in the proportion of migrant women.

The above, suggests the presence of a significant percentage of migrant women, although in fact by 1970 women already accounted for $50 \%$ of all international migrants, a percentage that would decrease four points over the next five decades and only two in 2016, reaching $48 \%$. Notwithstanding the fact that the relative participation of women declined slightly, the absolute volume increased more than 14 times over the period, from 338,000 to 5.5 million Mexican migrant women. In the case of men, their participation multiplied by 17 in the first five decades and then decreased, given the recent reduction in Mexican migration resulting from the economic crisis at the end of the last decade and the hardening of antiimmigrant policies in recent years, as evidenced by the analysis of growth rates by sex, in fact, the rates tend to converge again. The negative growth rate for men of -1.4 for 2016 is striking; we will have to wait for the 2020 data to confirm whether the presence of women will be greater in the next decade, although as noted above, the trend at least suggests equalization between men and women as in the 1970s and to a lesser extent in the 1980s. 
TABLE 1

POPULATION BORN IN MEXICO WITH RESIDENCE IN THE UNITED STATES 1970-2016

\begin{tabular}{|c|c|c|c|c|c|c|c|c|c|}
\hline \multirow{3}{*}{ Census Year } & \multicolumn{6}{|c|}{ Population in thousands and growth rate (\%) } & \multicolumn{3}{|c|}{ Percentage } \\
\hline & \multicolumn{2}{|c|}{ Total } & \multicolumn{2}{|c|}{ Men } & \multicolumn{2}{|c|}{ Women } & \multirow{2}{*}{ Total } & \multirow{2}{*}{ Men } & \multirow{2}{*}{ Women } \\
\hline & Absolute & TC & Absolute & TC & Absolute & TC & & & \\
\hline 1970 & 760 & & 377 & & 383 & & 100.0 & 49.6 & 50.4 \\
\hline 1980 & 2,199 & 11.2 & 1,153 & 11.8 & 1,047 & 10.6 & 100.0 & 52.4 & 47.6 \\
\hline 1990 & 4,298 & 6.9 & 2,370 & 7.5 & 1,929 & 6.3 & 100.0 & 55.1 & 44.9 \\
\hline 2000 & 9,178 & 7.9 & 5,084 & 7.9 & 4,093 & 7.8 & 100.0 & 55.4 & 44.6 \\
\hline 2010 & 11,711 & 2.5 & 6,543 & 2.6 & 5,329 & 2.7 & 101.4 & 55.9 & 45.5 \\
\hline 2016 & 11,568 & -0.2 & 6,024 & -1.4 & 5,545 & 0.7 & 100.0 & 52.1 & 47.9 \\
\hline
\end{tabular}

Source: Migration Policy Institute (MPI) tabulation of data from the U.S. Census Bureau's 2010-2016 American Community Surveys. Data from the 1970, 1990, and 2000 decennial Censuses.

In addition, it is important to remember the temporary/seasonal nature of Mexican migration that was prevalent during the $1970 \mathrm{~s}$ and $1980 \mathrm{~s}$, as well as the transition to a more permanent migration pattern beginning in the 1990s. If we assume that the eminently male and labor migration documented by different studies was not captured by the population censuses of that country, since they were interested in those formally established and with a more or less definitive residence (regardless of their migratory status), it sounds logical that there was a gender balance in the Mexican immigrants registered in the 1970 census and a little less in the 1980 census.

On the other hand, as the circular migration breaks down and a more permanent migration pattern emerges, some of the temporary migrants begin to be captured by the censuses and surveys of that country and, given that this migration was mostly made up of men, a greater participation of men in the stock of Mexican immigrants in the United States is beginning to be observed. In summary, before the 1990s there was a balance between men and women among permanent immigrants and a strong bias in favor of men among temporary migrants, which has been widely documented in the specialized literature. However, as temporary migrants become permanent and given the increasing presence of women, there will be a continuous increase in the participation of women in the volume or stock of migrants.

\section{Five-Year Flows of Mexican Migrant Women}

The information obtained from Mexican sources such as the Population Dynamics Surveys (ENADID, 1992, 1997, 1997, 2006, 2009 and 2014), the 1995 Population Count, the General Population and Housing Censuses of 2000 and 2010, as well as the Intercensal Survey, 2015, showed that the participation of women in the five-year emigration to the United States is relatively lower than that of men: approximately one woman for every four men, except in 2015 where the proportion of women changes to one woman for every three men (see Table 2). 
TABLE 2

FIVE-YEAR MIGRATION OF MEXICANS TO THE UNITED STATES, BY GENDER ${ }^{1}$

\begin{tabular}{|c|c|c|c|c|c|c|}
\hline \multirow{2}{*}{$\begin{array}{c}\text { Information sources according to } \\
\text { five-year reference period }\end{array}$} & \multicolumn{3}{|c|}{ Total in thousands } & \multicolumn{3}{|c|}{ Percentage } \\
\hline & Total & Men & Women & Total & Men & Women \\
\hline ENADID 1987-1992 & 1,865 & 1,382 & 483 & 100.0 & 74.1 & 25.9 \\
\hline Population count 1990-1995 & 1,713 & 1,191 & 522 & 100.0 & 69.5 & 30.5 \\
\hline ENADID 1992-1997 & 1,952 & 1,488 & 464 & 100.0 & 76.2 & 23.8 \\
\hline Census 1995-2000 & 1,235 & 917 & 318 & 100.0 & 74.2 & 25.8 \\
\hline ENADID 2001-2006 & 1,706 & 1,351 & 355 & 100.0 & 79.2 & 20.8 \\
\hline ENADID 2004-2009 & 1,640 & 1,258 & 382 & 100.0 & 76.7 & 23.3 \\
\hline Census 2005-2010 & 985 & 677 & 308 & 100.0 & 68.7 & 31.3 \\
\hline ENADID 2009-2014 & 621 & 479 & 142 & 100.0 & 77.1 & 22.9 \\
\hline Inter-census 2010-2015 & 559 & 360 & 200 & 100.0 & 64.3 & 35.7 \\
\hline
\end{tabular}

Note: ${ }^{1}$ Five-year migration refers to the population that moved to the United States during the five years prior to the time of the survey or census. Given the fact that most of the emigrants are no longer in the household (unless they have emigrated and returned during the same five-year period), the information provided by another household member who is present at the time of the survey. This could underestimate the presence of women in the flow, given that their departure means, in most cases, the emigration of the entire household.

Source: INEGI and CONAPO, National Survey of Demographic Dynamic (ENADID, 1992, 1997, 2006, 2009, and 2014); INEGI, Population and Housing Count, 1995; INEGI, General Population and Housing Census, 2000 and 2010; INEGI, Intercensal Survey, 2015.

Similarly, since 1995 there has been a downward tendency in the absolute and relative participation of women, for example, in the five-year period 1987-1992 there was an accumulated outflow of 483 thousand migrant women, while in the five-year period 2009-2014 their number barely reached 142 thousand, likewise, their participation in the total flow decreased from 26 to 23 percent during the same period. It is noteworthy, the most recent five-year period of analysis 2010-2015, although still predominantly for men, the participation of women reached the highest proportion with about 36 percent.

To explain the downward tendency in women's participation, the undesired effect of the tightening of border control policies by the United States immigration authorities, which have prolonged the length of stay of migrants in the United States, a phenomenon that has especially affected women, must be taken into account. ${ }^{6}$ Therefore, in the case of migrant women, at least three elements combine to explain their underregistration and why they are less and less likely to be included in this type of instrument: a) they are mostly permanent emigrants, b) with their departure, the possibility of another member of the household declaring them is frequently lost, and c) fewer and fewer women return to undertake a new migratory adventure and, in addition, more and more time elapses between the two migratory movements. ${ }^{7}$ In summary, it is known that the surveys in the place of origin may be collecting a lower proportion of migrant women, but this does not mean that their participation in the migratory phenomenon is lower, since women have assumed their own role within the phenomenon and not only that of accompanying men.

\section{Flow of Women Workers From Mexico to the U.S.}

Migration of temporary female workers to the United States is a historically significant phenomenon (CONAPO, 2000). According to the information collected by the Survey on Migration in Mexico's Northern Border (EMIF NORTE) displayed in Table 3 between 1995 and 2017 an annual average of almost 460 thousand migrants returned to Mexico after working for a time in the United States, of which 77 thousand were women representing 20 percent of the migration flow observed by the EMIF NORTE. In fact, Table 3 shows that although the majority of the migratory flow to the neighboring country is made up of men, it is noteworthy that women have increased their participation in both absolute and relative terms.

In this regard, it should be stated that the increase in female migration for the period of analysis seems to have been strongest between 1995 and 2001, when the participation of women tended to increase, 
reaching 25 percent in that year, and then declining to 10 percent in 2006, and then recovering again in 2010 and 2011 with 26 and 27 percent. Although the trend suggests an upward tendency, again towards the end of the period, with 35 percent in 2017, the percentage of women for the entire period of analysis, is lower than that corresponding to men, which is not the same as stating that their participation is lower in the migratory phenomenon, because as has already been advanced women have been increasingly assuming a more active role within the migratory phenomenon and the rest of the socioeconomic activities. ${ }^{8}$

TABLE 3

MIGRANT FLOWS FROM MEXICO TO THE UNITED STATES, 1995, 1999-2017

\begin{tabular}{|c|c|c|c|c|c|c|c|}
\hline \multirow[t]{2}{*}{ Year } & \multicolumn{4}{|c|}{ Total in thousands } & \multicolumn{3}{|c|}{ Percentage } \\
\hline & Total & & Men & Women & Total & Men & Women \\
\hline 1995 & & 415 & 399 & 16 & 100.0 & 96.1 & 39 \\
\hline 1999 & & 524 & 429 & 95 & 100.0 & 81.9 & 18.1 \\
\hline 2000 & & 455 & 362 & 92 & 100.0 & 79.7 & 20.3 \\
\hline 2001 & & 406 & 303 & 103 & 100.0 & 74.7 & 25.3 \\
\hline 2002 & & 729 & 615 & 114 & 100.0 & 84.4 & 15.6 \\
\hline 2003 & & 628 & 537 & 91 & 100.0 & 85.5 & 14.5 \\
\hline 2004 & & 542 & 482 & 60 & 100.0 & 88.9 & 11.1 \\
\hline 2005 & & 709 & 601 & 108 & 100.0 & 84.8 & 15.2 \\
\hline 2006 & & 816 & 730 & 85 & 100.0 & 89.6 & 10.4 \\
\hline 2007 & & 856 & 751 & 105 & 100.0 & 87.8 & 12.2 \\
\hline 2008 & & 748 & 608 & 140 & 100.0 & 81.3 & 18.7 \\
\hline 2009 & & 630 & 516 & 115 & 100.0 & 81.8 & 18.2 \\
\hline 2010 & & 493 & 365 & 128 & 100.0 & 74.1 & 25.9 \\
\hline 2011 & & 317 & 230 & 87 & 100.0 & 72.7 & 27.3 \\
\hline 2012 & & 276 & 228 & 48 & 100.0 & 82.6 & 17.4 \\
\hline 2013 & & 280 & 225 & 56 & 100.0 & 80.1 & 19.9 \\
\hline 2014 & & 165 & 125 & 40 & 100.0 & 75.7 & 24.3 \\
\hline 2015 & & 96 & 69 & 27 & 100.0 & 72.3 & 27.7 \\
\hline 2016 & & 76 & 53 & 23 & 100.0 & 69.7 & 30.3 \\
\hline 2017 & & 46 & 30 & 16 & 100.0 & 65.2 & 34.8 \\
\hline Average & & 460 & 383 & 77 & 100.0 & 80.4 & 19.6 \\
\hline
\end{tabular}

Source: UPM, CONAPO, INM, SER, STPS and EL COLEF, Surevey on Migration in MExico's Northern Border, 1994-1995 and 1999-2017

\section{Flow of Women Workers Sent Back by the United States Immigration Authorities}

The return of unauthorized migrants is one of the most sensitive issues in our relations with the United States. Consequently, in order to strengthen Mexico's positions in bilateral negotiations, it is essential to systematically monitor and analyze the transformations experienced by the phenomenon as a result of the interactions between border patrol strategies and the response of unauthorized migrants (CONAPO, 2000).

In this sense, the participation of women in the migratory flow to the neighboring country is one of the most worrisome social realities for the Mexican government and society, as they are one of the most vulnerable groups (CONAPO, 2000). Table 4 shows the participation of women in the flow of Mexican migrants returned by the United States, according to information from the EMIF NORTE, as can be seen during the 1995-2017 period, the EMIF NORTE observed an annual average of almost 450,000 returns of Mexican nationals who attempted to migrate in an irregular manner to the United States. From this total, 85 percent were men's returns and 15 percent were women's returns (see Table 4). The same table shows how the percentage of women returned by the immigration authorities has fluctuated over the last fifteen years between 11 and 20 percent, but with a decreasing trend. 
TABLE 4

MIGRANTS RETURNED BY UNITED STATES IMMIGRATION AUTHORITIES, 1995, 1999-2017

\begin{tabular}{|c|c|c|c|c|c|c|c|}
\hline \multirow[t]{2}{*}{ Year } & \multicolumn{4}{|c|}{ Total in thousands } & \multicolumn{3}{|c|}{ Percentage } \\
\hline & Total & & Men & Women & Total & Men & Women \\
\hline 1995 & & 637 & 536 & 101 & 100.0 & 84.1 & 15.9 \\
\hline 1999 & & 639 & 529 & 111 & 100.0 & 82.7 & 17.3 \\
\hline 2000 & & 808 & 662 & 146 & 100.0 & 82.0 & 18.0 \\
\hline 2001 & & 616 & 515 & 100 & 100.0 & 83.7 & 16.3 \\
\hline 2002 & & 570 & 468 & 102 & 100.0 & 82.2 & 17.8 \\
\hline 2003 & & 466 & 386 & 80 & 100.0 & 82.9 & 17.1 \\
\hline 2004 & & 429 & 363 & 66 & 100.0 & 84.6 & 15.4 \\
\hline 2005 & & 513 & 427 & 86 & 100.0 & 83.3 & 16.7 \\
\hline 2006 & & 462 & 373 & 90 & 100.0 & 80.6 & 19.4 \\
\hline 2007 & & 573 & 460 & 112 & 100.0 & 80.4 & 19.6 \\
\hline 2008 & & 566 & 470 & 95 & 100.0 & 83.2 & 16.8 \\
\hline 2009 & & 549 & 451 & 98 & 100.0 & 82.2 & 17.8 \\
\hline 2010 & & 418 & 365 & 53 & 100.0 & 87.2 & 12.8 \\
\hline 2011 & & 357 & 315 & 42 & 100.0 & 88.1 & 11.9 \\
\hline 2012 & & 352 & 308 & 44 & 100.0 & 87.4 & 12.6 \\
\hline 2013 & & 298 & 257 & 41 & 100.0 & 86.1 & 13.9 \\
\hline 2014 & & 214 & 186 & 29 & 100.0 & 86.7 & 13.3 \\
\hline 2015 & & 175 & 152 & 23 & 100.0 & 86.7 & 13.3 \\
\hline 2016 & & 197 & 175 & 22 & 100.0 & 88.8 & 11.2 \\
\hline 2017 & & 155 & 137 & 17 & 100.0 & 88.8 & 11.2 \\
\hline Average & & 450 & 377 & 73 & 100.0 & 84.6 & 15.4 \\
\hline
\end{tabular}

Source: UPM, CONAPO, INM, SER, STPS and EL COLEF, Surevey on Migration in MExico's Northern Border, 1994-1995 and 1999-2017

When we compare the flow towards the neighboring northern country with that of those returned by U.S. immigration authorities, as reported by EMIF NORTE, the results suggest an increasing trend in the participation of women in the case of the former, although the male predominance is maintained (see Table 5). In the case of the latter, it is difficult to confirm this assertion, since those returned by the U.S. authorities maintained participations that fluctuated throughout the analysis period, although with a decreasing trend. We believe that this growth behavior on the one hand and instability on the other have been related to the repeated economic crises in Mexico and in the neighboring country, as well as to the unexpected effects of some U.S. policies. ${ }^{9}$

TABLE 5

PERCENTAGE OF MEXICAN MIGRANT WOMEN GOING TO THE UNITED STATES AND RETURNED BY MIGRATION AUTHORITIES IN THE UNITED STATES, 1995, 1999-2017

\begin{tabular}{crr}
\hline & \multicolumn{3}{c}{ Mexican migrant women } \\
\cline { 2 - 4 } Year & From Mexico to the United States & \multicolumn{2}{c}{$\begin{array}{c}\text { Returned by United States immigration } \\
\text { authorities }\end{array}$} \\
\hline 1995 & 39 & 15.9 \\
1999 & 18.1 & 17.3 \\
2000 & 20.3 & 18.0 \\
2001 & 25.3 & 16.3 \\
2002 & 15.6 & 17.8 \\
\hline
\end{tabular}




\begin{tabular}{ccr}
\hline 2003 & 14.5 & 17.1 \\
2004 & 11.1 & 15.4 \\
2005 & 15.2 & 16.7 \\
2006 & 10.4 & 19.4 \\
2007 & 12.2 & 19.6 \\
2008 & 18.7 & 16.8 \\
2009 & 18.2 & 17.8 \\
2010 & 25.9 & 12.8 \\
2011 & 27.3 & 11.9 \\
2012 & 17.4 & 12.6 \\
2013 & 19.9 & 13.9 \\
2014 & 24.3 & 13.3 \\
2015 & 27.7 & 13.3 \\
2016 & 30.3 & 11.2 \\
2017 & 34.8 & 11.2 \\
Average & $\mathbf{1 9 . 6}$ & $\mathbf{1 5 . 4}$ \\
Source: UPM, CONAPO, INM, SER, STPS and EL COLEF, Surevey on Migration in MExico's Northern Border, \\
1994-1995 and 1999-2017 & \\
\hline
\end{tabular}

In summary, the evidence provided so far regarding the feminization of migration based on the analysis of the flow or "stock" yielded some elements that suggest that we could be facing the beginning of a process of feminization of Mexico-United States migration, in terms of an absolute and relative increase in the proportion of migrant women. Regarding the qualitative change linked to the term feminization, it is evident that a greater proportion of women in the Mexico-United States migration process will be associated with greater visibility of women who migrate independently in search of employment. ${ }^{10}$

\section{CONCLUDING THOUGHTS}

In this paper, we resume one of the most recent debates in the analysis of international migration regarding the feminization of migration, with the aim of answering the question: To what extent are we moving towards a quantitative feminization of Mexico-United States migration, given the changes in the gender distribution of migration flows?

We first approached the question by reviewing the literature, which showed that traditionally, research on international migration, and specifically on migrant workers to the United States, emphasized male participation. Women's migration was occasionally highlighted, it was assumed that women had less participation than men, and when reference was made to women in the migration process it was to describe their role as wives, partners, i.e. as a simple secondary presence in the rest of the family, so there was little recognition of women's independent activity in the migration process. It was taken as a fact that, by explaining the participation of migrant workers, the migration of women was also understood.

It was difficult to find a consensus in the literature regarding the quantitative participation of women in Mexico-United States migration. However, the papers reviewed alluded to the fact that women started to achieve numerical importance after the Immigration Reform and Control Act (IRCA) reforms in the United States in 1986. However, it was not enough to reach an agreement in terms of the volume represented by women's migration, due to the overwhelming predominance of male participation, but also because of the scarcity of information sources of national coverage that would allow us to know the different migratory patterns of the female population.

On the other hand, in this research it became clear not only that we have more and better sources of information, but also, from the analysis of the flow or "stock" it became evident that we could be facing the beginnings of a process of quantitative feminization of Mexico-United States migration, in terms of an absolute and relative increase in the proportion of migrant women. 
The aforementioned reinforces the idea of greater visibility of women in terms of employment, a product of the economic and social changes in Mexico and the rest of the world that have resulted in the greater incorporation of women into the labor market, putting pressure on men who cannot play the traditional role of economic providers and on women to seek new strategies for family survival, such as international migration, where they have assumed their own role within the phenomenon and not only that of simple partners of men. In fact, it is held that feminization, with its limitations, may refer not only to the greater volume of women, but also to the increasing presence of women in the labor market, as well as their independent migration in search of work, instead of doing so as family "dependents", traveling with their husbands or joining them abroad.

In short, the migrant woman is a social protagonist of great relevance who modifies, incorporates and interrelates with both the social, economic and cultural context of her community of origin and that of the community of destination, and it is precisely the migrant woman who can help us to respond and understand what is happening at this moment.

\section{ACKNOWLEDGEMENT}

Translated \& edited by American Publishing Services (https://americanpublishingservices.com/).

\section{ENDNOTES}

1. The interested reader can review the work (SANTIAGO and BERUMEN, 2012), in which the second hypothesis is explored in greater detail.

2. It was not assumed that women did not migrate; it was assumed that they migrated as subordinate partners of a male or for family reunification purposes (PESSAR, 1999; POGGIO and WOO, 2000).

3. The Immigration Reform and Control Act (IRCA) of 1986 prohibits employment discrimination based on national origin or citizenship status. At the same time, IRCA requires companies to verify that all employees, whether citizens or non-citizens, are authorized to work in the United States.

4. The authors referred to above point out the changes that have taken place in the migratory flow and in the characteristics of the migrant population after the approval of the Simpson-Rodino Act, among which the growing participation of women stands out.

5. In addition to feminization, other characteristics of modern migration are globalization (a greater number of countries are affected by this phenomenon); acceleration (the number of migrants at the international level increases exponentially in a more dynamic way than in previous historical periods); differentiation (migrants moving to a given country generally share a common ethnic, class and gender background); and politicization (national migration policy projections are impacted by a set of considerations pertaining to the field of international relations and national security and vice versa) (CASTLES and MILLER, 1998).

6. The literature has called this phenomenon the attrition of circular migration and its effect has been greater in the case of women (see CORONA and TUIRÁN, 2001). See about the length of stay of return migrants to (SANTIAGO, 2018).

7. See a more detailed analysis on the return of Mexican return migrants to (SANTIAGO, DE JESUS and DELGADILLO, 2018).

8. See (SANTIAGO and BERUMEN, 2012), specifically the section: The presence of women in the labor market in Mexico and Mexican emigration to the United States.

9. Two United States immigration policy actions have had a particular impact on the change in the volume of the Mexican female population in the United States: the first refers to the application of the Simpson Rodino Act, which, in addition to granting amnesty in that country to undocumented workers who met specific requirements, promoted family reunification, allowing many families of the beneficiaries who had remained in their place of origin (in this case, Mexico) to enter that country in a documented manner (VERNEZ, 1999); The second highlights that U.S. reforms focused on the control and militarization of the border with Mexico have contributed to reduce the process of Mexican circular migration and favored the more permanent residence of our nationals in that country (ANGOA, 2009).

10. See (SANTIAGO y BERUMEN, 2012). 


\section{REFERENCES}

American Community Survey Data. (n.d.). MIGRATION POLICY INSTITUTE (MPI) tabulation of data from the U.S. Census Bureau's 2010-2016 American Community Surveys. Data from the 1970, 1990, and 2000 decennial Censuses.

Angoa, M.A. (2009). Mexicanas en Estados Unidos. In P. Leite \& S.E. Giorguli (coords.), El estado de la migración. Las políticas públicas ante los retos de la migración mexicana a Estados Unidos. México, CONAPO.

Arroyo Alejandre J., De León Arias, A., \& Valenzuela Varela, M.B. (1991). Migración rural hacia Estados Unidos: Un estudio regional en Jalisco. Guadalajara, México, Consejo Nacional para la Cultura y las Artes, Universidad de Guadalajara.

Bustamante, J. (1988). Migración de indocumentados de México a Estados Unidos. Fundación Friedrich Ebert Stiftung, México.

Castles, S., \& Miller, M.J. (1998). The age of migration: International population movement in the modern world. New York: The Guilford Press.

CONAPO. (n.d.). Encuesta sobre Migración en la Frontera Norte (EMIF NORTE) 1994-1995 y 19992017.

Consejo Nacional De Población. (2000). Mujeres en la Migración a Estados Unidos. Migración Internacional, 5(13). México, CONAPO. ISSN 1405-5589

Cornelius, W.A. (1988, November). Los migrantes de la crisis: The changing profile of Mexican labor migration to California in the 1980s (pp. 18-30). Paper presented in Population and work in regional setting, El Colegio de Michoacán, Zamora.

Corona, R., \& Tuirán, R. (2001). La migración internacional desde y hacia México. In J. Gómez \& C. Rabell (Coords.), La población de México. Tendencias y perspectivas sociodemográficas hacia el siglo XXI. México, CONAPO.

González De La Rocha, M., \& Escobar Latapí, A. (1990). Efecto de IRCA en los patrones migratorios de una comunidad en Los Altos de Jalisco, (mimeo).

INEGI. (1992). Encuesta Nacional de la Dinámica Demográfica (ENADID).

INEGI. (1995). Conteo de Población y Vivienda.

INEGI. (1997). Encuesta Nacional de la Dinámica Demográfica (ENADID).

INEGI. (2000). XII Censo General de Población y Vivienda.

INEGI. (2006). Encuesta Nacional de la Dinámica Demográfica (ENADID).

INEGI. (2009). Encuesta Nacional de la Dinámica Demográfica (ENADID).

INEGI. (2010). XIII Censo General de Población y Vivienda.

INEGI. (2014). Encuesta Nacional de la Dinámica Demográfica (ENADID).

INEGI. (2015). Encuesta Intercensal.

Kossoudji, S.A., \& Ranney, S.I. (1984). The labor market experience of female migrants: The case of temporary Mexican migration to the U.S. International Migration Review, 18(4), 1120-43.

Leite, P., Angoa, M.A., \& Rodríguez, M. (2009). Emigración México-Estados Unidos: Balance de las últimas décadas. In La Situación demográfica de México (pp. 103-23). CONAPO, México.

Martínez, P.J. (2003). El mapa migratorio de América Latina y el Caribe, las mujeres y el género. Santiago de Chile, UNFPA.

Mines, R., \& De Janvry, A. (1982). Migration to theUnited States and Mexican Rural Development: A case Study. American Journal of Agricultural Economics, 64(3), 444-454.

ONU. (2006). Estudio mundial sobre el papel de la mujer en el desarrollo 2004. La mujer y la migración internacional. Departamento de Asuntos Económicos y Sociales. División para el Adelanto de la Mujer. Naciones Unidas, Nueva York.

Pessar, P.R. (1999). Engendering Migration Studies: The case of the new immigrants in the United States. American Behavioral Scientist, 42(4), 577-600.

Poggio, S., \& Woo, O. (2000). La invisibilidad de las mujeres en la emigración hacia Estados Unidos. In Migración femenina hacia (pp. 7-20). Estados Unidos, México, EDAMEX. 
Reichert, J.S. (1981). The Migrant Syndrome: Seasonal U.S. Wage Labor and Rural Development in Central Mexico. Human Organization, 40(1), 56-66.

Reichert, J.S., \& Massey, D.S. (1979). Patterns of Migration from a Mexican Sending Community: A Comparison of Legal and Illegal Migrants. International Migration Review, 13(4), 599-623.

Santiago Hernández, J. (2018). Análisis de la duración de las estancias de los migrantes mexicanos de retorno. El Colegio de Jalisco, México.

Santiago Hernández, J., \& Berumen Sandoval, S. (2012). Las mujeres en el proceso migratorio MéxicoEstados Unidos. ¿Hacia una feminización de la migración? In S. Berumen Sandoval, N. Frías Valle, \& J. Santiago Hernández (Coords.), Migración y familia. Una mirada más humana para el estudio de la migración internacional. SPMAR-UPM-CEM, TILDE EDITORES, INM.

Santiago Hernández, J., De Jesus Desidério, E., \& Delgadillo Aguilar, N. (2018). ¿Quiénes son los que regresan? Escenarios de la migración de retorno a México según la Encuesta Nacional de Empleo

y Ocupación 2010-2016. En Livro Migrações Sul-Sul, Fondo de Población de las Naciones Unidas (UNFPA), Fapesp.

Vernez, G. (1999). Immigrant Women in the U.S. Workforce. Who struggles? Who Succeeds? Lanham, MD, Lexington Books.

Villa, M., \& Martínez, J. (2002, May-August). Rasgos sociodemográficos y económicos de la migración internacional en América Latina y el Caribe. Capítulos del SELA, 65, 26-67.

Woo Morales, O. (1995). Las mujeres mexicanas indocumentadas en la migración internacional y la movilidad transfronteriza. In S. González, O. Ruiz, L. Velasco, \& O. Woo (Comps.), Mujeres, migración y maquila en la frontera norte. México, El Colegio de México/El Colegio de la Frontera Norte.

Woo Morales, O. (2007). Memoria: Mujeres afectadas por el fenómeno migratorio en México. Una aproximación desde la perspectiva de género, México, Instituto Nacional de las Mujeres. Dirección General de Promoción y Enlace. Dirección de Desarrollo Social y Humano.

Zlotnik, H. (2003). The global dimensiones of female migration. Retrieved from www.migrationinformation.org 